\title{
Grain growth and distribution of dry matter in the wheat plant as influenced by temperature, light energy and ear size
}

\author{
J. H. J. Spiertz \\ Department of Field Crops and Grassland Husbandry, Agricultural University, the \\ Netherlands
}

Accepted: 12 August 1974

\begin{abstract}
Summary
An experiment was carried out under controlled growing conditions to study the plant response during the postfloral stage to temperature, light intensity and ear size. Within the range of 15 to $25^{\circ} \mathrm{C}$ a raise in temperature increased the growth rate of the grains but the duration of the post-floral development of the plant was very much shortened. The final result was that higher temperatures caused lower grain yields. An increase of light intensity from 92 to $147 \mathrm{cal} \mathrm{cm}^{-2}$ day-1 has shown a more positive effect on grain weight than an increase from 147 to $175 \mathrm{cal} \mathrm{cm}^{-2}$ day ${ }^{-1}$. The artificial reduction of ear size by removing spikelets from the ear increased the thousand-grain weight but not enough to compensate for the reduction in number of kernels per ear.

The effects of the main factors - temperature, light intensity and ear size - and of the combined treatments on the supply and storage of carbohydrate are discussed within the framework of a sink-source model.
\end{abstract}

\section{Introduction}

Grain yield in a wheat plant is partly determined in the pre-floral period, for instance by the size of the photosynthetic area and the potential number of kernels per ear, but mainly in the post-floral period by the rate and the duration of grain growth. Before ear initiation, tillering and leaf production are affected by temperature and light intensity (Friend, 1965); during the booting stage temperature has a strong influence on the developmental rate (Friend, 1966), while light intensity determines the number of ears per plant and the development of the spikelets (Puckridge, 1968; Willey, 1965).

The supply of assimilates to the growing organs depends on the activity and the duration of photosynthesis in the green organs of the plant, mainly the leaves. A rather complete description of the contribution by each leaf to the total pool of assimilates available for growth and the translocation at different stages is presented by Rawson \& Hofstra (1969). They concluded that the lower leaves mainly contribute their assimilates to the roots and the side tillers, while the top leaves provide the assimilate requirements of stem and ear. Much research has been done on the source function of the flag leaf, the peduncle and the ear (Stoy, 1965; Carr \& Wardlaw, 1965; Lupton, 1972; Evans \& Rawson, 1970, and many others) in relation to the sink demand of the grains. Often there was evidence that leaf area and the rate of photosynthesis did not limit the supply of assimilates in the early stages of grain growth. 


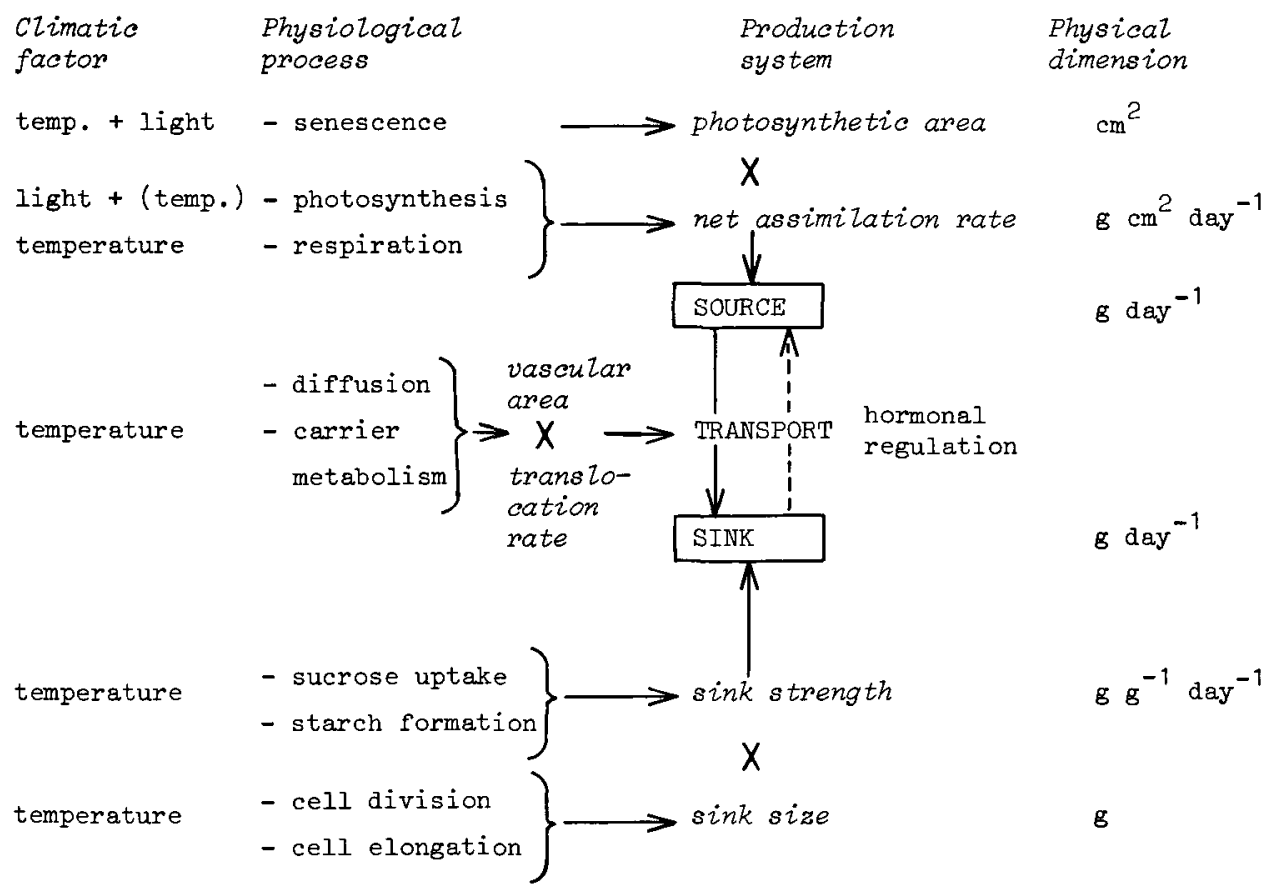

Fig. 1 Model for grain growth.

For that reason more attention has been paid to other possible limiting factors in grain growth, in particular:

- the transport through the vascular system (Evans et al., 1970; Hanif \& Langer, 1972);

- all the processes involved in converting sucrose to starch in the endosperm cells (Jenner \& Rathjen, 1972);

- the pattern of the grain growth within the ear (Rawson \& Evans, 1970; Walpole \& Morgan, 1970; Bremner, 1972).

There is evidence, too, that a hormonal mechanism regulates the attraction and the competition for assimilates within the ear (Michaël et al., 1970).

The rate of grain growth in wheat is related to various physiological processes. The connections between these processes can be illustrated within a sink-source model (Fig. 1). As the model shows, assimilate supply (source) is determined by light energy and temperature, while transport and sink capacity are influenced by temperature in many ways. In the single plant situation, temperature has a key function in grain growth; in the crop situation, light may be more important due to mutual shading. At present knowledge about the influence of temperature is rather scarce. To study the effect of temperature on the relationship between sink and source during the post-floral period, an experiment was carried out in a controlled environment with four temperature treatments, combined with three levels of light intensity and three ear sizes. 


\section{Material and methods}

The experiments were done in the phytotron of the Department of Field Crops and Grassland Husbandry of the Agricultural University, Wageningen.

Seeds of the spring wheat variety Orca with a diameter of $3.0-3.4 \mathrm{~mm}$ were used for the experiments. In 240 pots filled with $5 \mathrm{~kg}$ soil consisting of $50 \%$ sand and $50 \%$ marine clay, 20 seeds were sown at random; two weeks after germination the number of seedlings was reduced to 15 per pot (area $=300 \mathrm{~cm}^{2}$ ). To prevent seedborne diseases and mildew the seeds were dressed with Aatisan and Milstem; during the growing period insecticides and fungicides were applied regularly. The plants grew under natural daylength and a temperature regime of $15^{\circ} \mathrm{C}$ during the day and $10^{\circ} \mathrm{C}$ at night.

From flowering onwards the following treatments were applied:

$\begin{array}{lllll}\text { Group A } & \mathrm{T}_{1} & \mathrm{~T}_{2} & \mathrm{~T}_{3} & \mathrm{~T}_{4} \\ & & & & \\ \text { I - } 4 \text { temperatures: day } & 15{ }^{\circ} \mathrm{C} & 15^{\circ} \mathrm{C} & 25^{\circ} \mathrm{C} & 25^{\circ} \mathrm{C} \text { (16 hours) } \\ & 15{ }^{\circ} \mathrm{C} & 25^{\circ} \mathrm{C} & 15^{\circ} \mathrm{C} & 25^{\circ} \mathrm{C} \text { ( 8 hours) } \\ \text { II - 3 light intensities: } & \mathrm{L}_{1} & \mathrm{~L}_{2} & \mathrm{~L}_{3} & \\ & 92 & 146 & 175 & \text { cal cm-2 day-1 }\end{array}$

III - 3 ear sizes: by artificially removing some spikelets at flowering the number of kernels was reduced. In 120 pots each with 15 main culms, five ears were kept at normal length, from five ears the top spikelets and from another five ears the top and the central spikelets were removed. This interference resulted in three groups of five ears each with a different number of kernels (as a mean for the light and temperature treatments): $S_{0}: 47.0$ kernels per ear (control); $S_{1}: 36.6$ kernels per ear; $S_{2}: 24.3$ kernels per ear.

\section{Group $B$}

The same treatments as $A_{1}$ and $A_{2}$, however, with an additional cold treatment $\left(2{ }^{\circ} \mathrm{C}\right)$ of soaked seeds at germination. This resulted in a one week delay of flowering and in an additional 1.3 spikelet per ear.

The pots were fertilized weekly or fortnightly with a mineral solution of $\mathrm{NH}_{4} \mathrm{NO}_{3}$, $\mathrm{Ca}\left(\mathrm{NO}_{3}\right)_{2}, \mathrm{KNO}_{3}, \mathrm{KH}_{2} \mathrm{PO}_{4}$ and $\mathrm{MgSO}_{4}$. The total amount of minerals for the whole growing period was (in meq per pot): $27.5 \mathrm{NH}_{4}+$; $95 \mathrm{NO}_{3}-; 70 \mathrm{~K}+; 12.5 \mathrm{Ca}^{2}+$; $25 \mathrm{Mg}^{2}+; 32.5 \mathrm{H}_{2} \mathrm{PO}_{4}$-; and $22.5 \mathrm{SO}_{4}{ }^{2}-$. The micro-elements were applied once at the beginning of the growing period.

Observations were made on the following dates:

$\begin{array}{lcclllll} & \mathrm{H}_{0} & \mathbf{H}_{1} & \mathbf{H}_{2} & \mathbf{H}_{3} & \mathbf{H}_{4} & \mathbf{H}_{5} & \mathbf{H}_{6} \\ \mathrm{~T}_{1}=15 / 15^{\circ} \mathrm{C} & 20 / 8 & 9 / 9 & - & 22 / 9 & - & 6 / 10 & 13 / 10 \\ \mathrm{~T}_{2}=15 / 25^{\circ} \mathrm{C} & 20 / 8 & 9 / 9 & - & 22 / 9 & - & 6 / 10 & 13 / 10 \\ \mathrm{~T}_{3}=25 / 15^{\circ} \mathrm{C} & 20 / 8 & 9 / 9 & 17 / 9 & 22 / 9 & 29 / 9 & - & - \\ \mathrm{T}_{4}=25 / 25^{\circ} \mathrm{C} & 20 / 8 & 9 / 9 & 17 / 9 & 22 / 9 & 29 / 9 & - & -\end{array}$

At the intermediate and at the final harvest the measurements were carried out on the main culms. To determine dry matter weights and leaf area the culms were separated into:

a) flag leaf, other green leaves and dead leaves; 
b) peduncle and remaining internodes;

c) ear; in some cases divided into the top, the central and the basal part.

The side culms were separated into ears straw. Stubble and root weights were determined together for all culms per pot.

After 18 hours drying at $70^{\circ} \mathrm{C}$ the individual samples were weighed and the ears were treshed. The anthrone method (Yemm \& Willis, 1954) was used to determine the content of water-soluble carbohydrate by an auto-analyser.

The measurements of photosynthesis and respiration with the Gilson respirometer were carried out on small parts, about $200 \mathrm{mg}$ fresh weight, of the flag leaf, the peduncle and the ear (one or two spikelets); under steady state conditions photosynthesis and respiration were measured during 4 intervals of 15 minutes.

\section{Results}

Analysis of variance

In the first analysis of the effects of the four temperature treatments, the main effects of 15 and $25^{\circ} \mathrm{C}$ during day-time and at night were calculated. The effect of temperature during day-time was mostly twice as large as that of the night temperature, but

Table 1. The effects of various treatments on the weight of the components of the main culm (Group A).

\begin{tabular}{|c|c|c|c|c|c|c|c|c|c|}
\hline Component & Date & Mean & c.v. & $\begin{array}{l}\text { Ear } \\
\text { size } \\
(\mathbf{S})\end{array}$ & $\begin{array}{l}\text { Tempera- } \\
\text { ture } \\
\text { (T) }\end{array}$ & $\begin{array}{l}\text { Light } \\
\text { (L) }\end{array}$ & $\mathrm{S} \times \mathrm{L}$ & $\mathrm{S} \times \mathrm{T}$ & $L \times T$ \\
\hline $\begin{array}{l}\text { 1. weight per ear } \\
\text { (mg) }\end{array}$ & $\begin{array}{l}20 / 8 \\
9 / 9 \\
22 / 9 \\
\text { ripeness }\end{array}$ & $\begin{array}{r}473 \\
1289 \\
1874 \\
2248\end{array}$ & $\begin{array}{l}-\overline{1} \\
6.7 \\
5.7 \\
4.4\end{array}$ & $\begin{array}{l}- \\
* * * \\
* * * \\
* * *\end{array}$ & $\begin{array}{l}- \\
* * * \\
* * * \\
* * *\end{array}$ & $\begin{array}{l}- \\
* * * \\
* * * \\
* * *\end{array}$ & $\begin{array}{l}- \\
* * * \\
* \\
\text { n.s. }\end{array}$ & $\begin{array}{l}- \\
\mathrm{n} . \mathrm{s} . \\
* * \\
* *\end{array}$ & $\begin{array}{l}- \\
\text { n.s. } \\
\text { n.s. } \\
*\end{array}$ \\
\hline $\begin{array}{l}\text { 2. seed weight } \\
\text { per main ear } \\
\text { (mg) }\end{array}$ & $\begin{array}{l}9 / 9 \\
22 / 9 \\
\text { ripeness }\end{array}$ & $\begin{array}{r}897 \\
1456 \\
1603\end{array}$ & $\begin{array}{r}14.3 \\
7.0 \\
6.4\end{array}$ & $\begin{array}{l}* * * \\
* * * \\
* * *\end{array}$ & $\begin{array}{l}* * * \\
* * * \\
* * *\end{array}$ & $\begin{array}{l}* * * \\
* * * \\
* * *\end{array}$ & $\begin{array}{l}\text { n.s. } \\
* \\
\text { n.s. }\end{array}$ & $\begin{array}{l}\text { n.s. } \\
* \\
*\end{array}$ & $\begin{array}{l}\text { n.s. } \\
\text { n.s. } \\
*\end{array}$ \\
\hline $\begin{array}{l}\text { 3. kernel weight } \\
\text { (mg) }\end{array}$ & $\begin{array}{l}9 / 9 \\
22 / 9 \\
\text { ripeness }\end{array}$ & $\begin{array}{l}25.3 \\
43.6 \\
44.3\end{array}$ & $\begin{array}{l}5.9 \\
3.6 \\
6.4\end{array}$ & $\begin{array}{l}* * * \\
* * * \\
* * *\end{array}$ & $\begin{array}{l}* * * \\
* * * \\
* * *\end{array}$ & $\begin{array}{l}* * * \\
* * * \\
\text { n.s. }\end{array}$ & $\begin{array}{l}\text { n.s. } \\
* \\
\text { n.s. }\end{array}$ & $\begin{array}{l}\text { n.s. } \\
\text { n.s. } \\
\text { n.s. }\end{array}$ & $\begin{array}{l}* \\
* \\
\text { n.s. }\end{array}$ \\
\hline $\begin{array}{l}\text { 4. number of kernels } \\
\text { (mg) }\end{array}$ & $\begin{array}{r}9 / 9 \\
22 / 9\end{array}$ & $\begin{array}{l}36.0 \\
33.4\end{array}$ & $\begin{array}{r}13.1 \\
5.3\end{array}$ & $\begin{array}{l}* * * \\
* * *\end{array}$ & $\begin{array}{l}\text { n.s. } \\
*\end{array}$ & $\begin{array}{l}\text { n.s. } \\
*\end{array}$ & $\begin{array}{l}\text { n.s. } \\
\text { n.s. }\end{array}$ & $\begin{array}{l}\text { n.s. } \\
\text { n.s. }\end{array}$ & $\begin{array}{l}\text { n.s. } \\
\text { n.s. }\end{array}$ \\
\hline $\begin{array}{l}\text { 5. weight of } \\
\text { peduncle (mg) }\end{array}$ & $\begin{array}{l}9 / 9 \\
22 / 9 \\
\text { ripeness }\end{array}$ & $\begin{array}{l}556 \\
479 \\
462\end{array}$ & $\begin{array}{l}6.5 \\
4.8 \\
4.6\end{array}$ & $\begin{array}{l}* * \\
* * * \\
* * *\end{array}$ & $\begin{array}{l}* * * \\
* * * \\
* * *\end{array}$ & $\begin{array}{l}* * * \\
\text { n.s. } \\
\text { n.s. }\end{array}$ & $\begin{array}{l}\text { n.s. } \\
\text { n.s. } \\
\text { n.s. }\end{array}$ & $\begin{array}{l}\text { n.s. } \\
\text { n.s. } \\
\text { n.s. }\end{array}$ & $\begin{array}{l}\text { n.s. } \\
\text { n.s. } \\
\text { n.s. }\end{array}$ \\
\hline $\begin{array}{l}\text { 6. weight of the } \\
\text { other internodes } \\
\text { (mg) }\end{array}$ & $\begin{array}{l}9 / 9 \\
22 / 9 \\
\text { ripeness }\end{array}$ & $\begin{array}{r}1134 \\
961 \\
906\end{array}$ & $\begin{array}{l}8.3 \\
5.2 \\
3.5\end{array}$ & $\begin{array}{l}* * \\
* * * \\
* * *\end{array}$ & $\begin{array}{l}* * * \\
* * * \\
* * *\end{array}$ & $\begin{array}{l}* * * \\
* \\
\text { n.s. }\end{array}$ & $\begin{array}{l}\text { n.s. } \\
\text { n.s. } \\
\text { n.s. }\end{array}$ & $\begin{array}{l}\text { n.s. } \\
\text { n.s. } \\
\text { n.s. }\end{array}$ & $\begin{array}{l}\text { n.s. } \\
\text { n.s. } \\
\text { n.s. }\end{array}$ \\
\hline $\begin{array}{l}\text { 7. weight of the } \\
\text { leaves }(\mathrm{mg})\end{array}$ & $\begin{array}{l}9 / 9 \\
22 / 9 \\
\text { ripeness }\end{array}$ & $\begin{array}{l}540 \\
502 \\
436\end{array}$ & $\begin{array}{l}9.3 \\
8.4 \\
8.8\end{array}$ & $\begin{array}{l}\text { n.s. } \\
\text { n.s. } \\
\text { n.s. }\end{array}$ & $\begin{array}{l}\text { n.s. } \\
* * \\
* * *\end{array}$ & $\begin{array}{l}\text { n.s. } \\
\text { n.s. } \\
\text { n.s. }\end{array}$ & $\begin{array}{l}\text { n.s. } \\
\text { n.s. } \\
\text { n.s. }\end{array}$ & $\begin{array}{l}\text { n.s. } \\
\text { n.s. } \\
\text { n.s. }\end{array}$ & $\begin{array}{l}\text { n.s. } \\
\text { n.s. } \\
*\end{array}$ \\
\hline $\begin{array}{l}\text { 8. total aerial } \\
\text { weight of main } \\
\text { culm (mg) }\end{array}$ & $\begin{array}{l}9 / 9 \\
22 / 9 \\
\text { ripeness }\end{array}$ & $\begin{array}{l}3520 \\
3816 \\
3792\end{array}$ & $\begin{array}{l}3.8 \\
3.7 \\
3.7\end{array}$ & $\begin{array}{l}* * * \\
* * * \\
* * *\end{array}$ & $\begin{array}{l}* *: ; \\
* * * \\
* * *\end{array}$ & $\begin{array}{l}* * * \\
* * * \\
* * *\end{array}$ & $\begin{array}{l}* \\
\text { n.s. } \\
\text { n.s. }\end{array}$ & $\begin{array}{l}\text { n.s. } \\
* \\
*\end{array}$ & $\begin{array}{l}\text { n.s. } \\
\text { n.s. } \\
*\end{array}$ \\
\hline
\end{tabular}

n.s.: $\alpha>0.05 ; \mathrm{x}: 0.05 \geqslant \alpha>0.01 ; \mathrm{xx}: 0.01 \geqslant \alpha>0.001 ; \mathrm{xxx} \alpha \leqslant 0.001$. 
Table 2. The analysis of variance by means of a multiple regression with real variables.

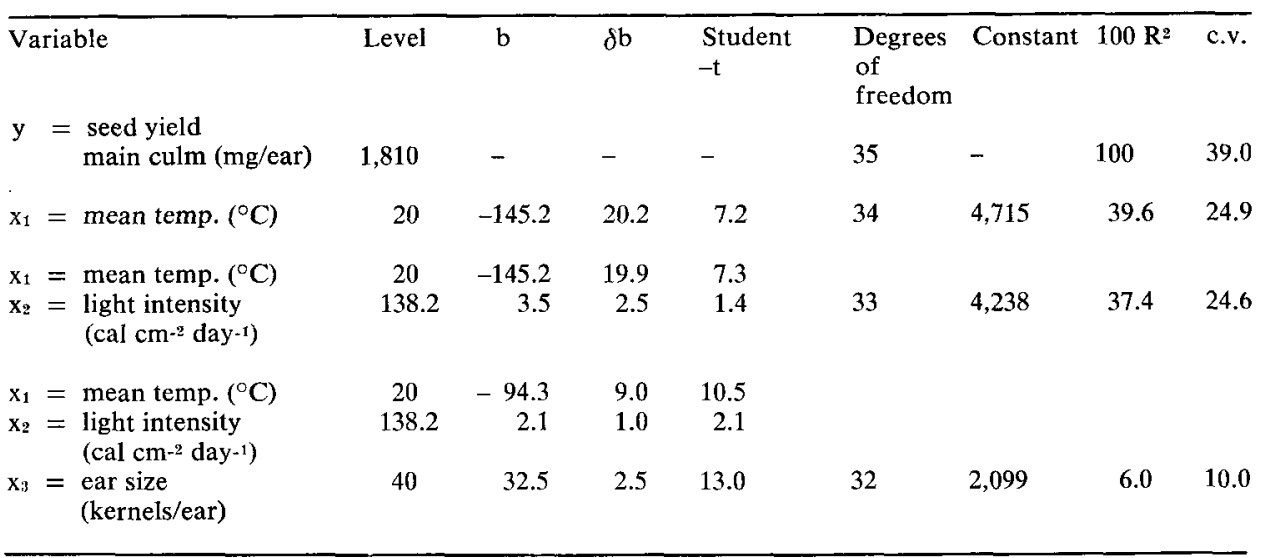

also the day-length ( 16 hours) was twice the night period ( 8 hours). For that reason the four temperature treatments $-15 / 15^{\circ} \mathrm{C}, 15 / 25^{\circ} \mathrm{C}, 25 / 15^{\circ} \mathrm{C}$ and $25 / 25{ }^{\circ} \mathrm{C}$ - will be considered as mean daily temperatures of $15,18.3,21.7$ and $25^{\circ} \mathrm{C}$.

The experiment was carried out as a split-plot design with the factor temperature in the main split and light in the sub-split. The results of the analysis of variance for the components of the main culm (Group A) are presented in Table 1. All the parameters which are related with grain growth, were strongly influenced by the main factors: ear size, light intensity and temperature.

The first-order interactions were of minor importance. The results of Group B were of the same magnitude.

By means of a multiple regression analysis with all main factors and first-order interactions as dummy variables, the coefficient of variation for the seed yield of the main culm was decreased from 39.0 to $8.9 \%$. Thereby temperature, light intensity and ear size accounted for 74.0, 2.1 and $18.8 \%$ of the variance in seed yield respectively. The calculations with real variables gave about the same results (Table 2).

A change in temperature caused a decrease of $94.3 \mathrm{mg} \mathrm{seed} / \mathrm{culm}$ per ${ }^{\circ} \mathrm{C}$ and a change in light intensity or ear size gave an increase of 2.1 and $32.5 \mathrm{mg}$ seed/culm, per calorie and per kennel, respectively. So the total reponse of seed yield to temperature is negative mainly due to the earlier senescence of the plants. An increase in light intensity or in number of kernels per ear resulted in a higher seed yield per culm.

\section{Influence of temperature}

During the post-floral period the growth rate of the kernels increased with rising temperature, but the senescence of the leaves and other green parts of the plant also increased. The resultant of these opposite processes was an initially higher growth rate during a relatively short period at $25^{\circ} \mathrm{C}$ and a slower growth rate during a long period at $15^{\circ} \mathrm{C} ; 18.3^{\circ}$ and $21.7{ }^{\circ} \mathrm{C}$ were intermediate in their effect upon growth rate and senescence (Fig. 2). The acceleration of leaf senescence and ripening of the kernels by higher temperatures was more important for the ultimate grain yield than the increase of the growth rate. The period between flowering and a dry matter content in the ear of $65 \%$ has lasted 52, 40,31 and 26 days for 15, 18.3, 21.7 and 

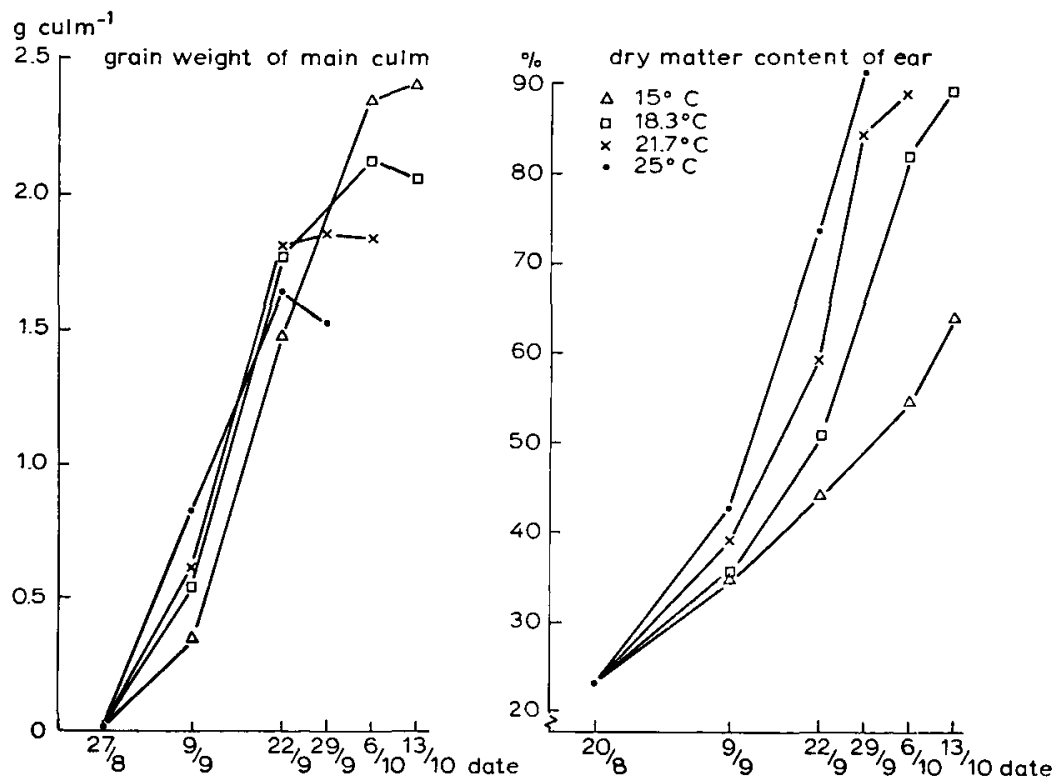

Fig. 2. The influence of temperature on grain growth and dry matter content of the ear (data of Group B).

$25^{\circ} \mathrm{C}$, respectively. Thus the kernel filling period was doubled by a decrease in temperature of $10^{\circ} \mathrm{C}$.

The influence of temperature on leaf area duration is demonstrated by the leaf area at three weeks after flowering; a decrease from $63,47,34$ to $21 \mathrm{~cm}^{2}$ per culm within the temperature range $15-25^{\circ} \mathrm{C}$. Which factor first stops grain growth is not clear; there is some evidence that it might be the supply of assimilates, because at the highest temperature grain growth stopped at a dry matter content in the ear of about $40 \%$, while at $15{ }^{\circ} \mathrm{C}$ grain growth continued op to $65 \%$ dry matter. There are many literature sources, which report a physiological limit for grain growth at $35 \%$ moisture content. This percentage will be somewhat lower for the ears, because the rachilla and the glumes contain less moisture than the kernels.

The distribution of the assimilates was also influenced by temperature (Fig. 3). With higher temperatures more assimilates were used for grain growth at the expense of the weight of the internodes and perhaps also of the roots. The weight of the peduncle increased during the first two weeks after flowering and from that time onwards the peduncle weight decreased slowly, whereas the weight of the other internodes dropped sharply after flowering, especially at higher temperatures.

This decrease in dry matter weight of the stem was greater than the gain in kernel weight. Therefore the supply of assimilates to the grains by remobilization out of the stem may only have been a part of the loss in weight. Much more of the weight loss was caused by the increase of respiration at higher temperatures. This can be illustrated by a few measurements of photosynthesis and respiration with a Gilson respirometer, taken at 15 and $25^{\circ} \mathrm{C}$ (Table 3 ) for the four temperature treatments.

The increase of temperature gave a $Q_{10}$ value for the respiration of more than 2 as a 


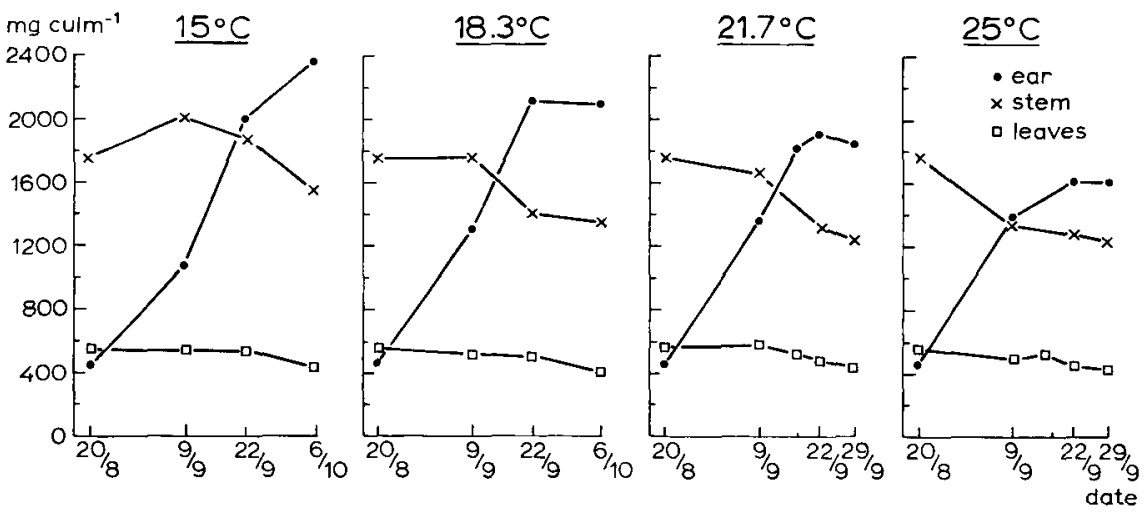

Fig. 3. The influence of temperature on dry matter distribution after flowering (data of Group A).

Table 3. The magnitude of photosynthesis in flag leaf and of respiration in flag leaf, peduncle and ear at the milk to dough ripe stage $\left(\mu 1 \mathrm{O}_{2} / \mathrm{g}\right.$ fresh weight/minute).

\begin{tabular}{|c|c|c|c|c|c|c|c|}
\hline & \multicolumn{3}{|l|}{ Flag leaf } & \multirow{2}{*}{\multicolumn{2}{|c|}{$\frac{\text { Peduncle }}{\text { dark respiration }}$}} & \multirow{2}{*}{\multicolumn{2}{|c|}{$\frac{\text { Ear }}{\text { dark respiration }}$}} \\
\hline & \multirow{2}{*}{$\frac{\text { photosynthesis }}{15^{\circ} \mathrm{C}}$} & \multicolumn{2}{|c|}{ dark respiration } & & & & \\
\hline & & $15^{\circ} \mathrm{C}$ & $25^{\circ} \mathrm{C}$ & $15^{\circ} \mathrm{C}$ & $25^{\circ} \mathrm{C}$ & $15^{\circ} \mathrm{C}$ & $25^{\circ} \mathrm{C}$ \\
\hline $\mathbf{T}_{1}: 15 / 15$ & 44.0 & 7.6 & 19.2 & 3.1 & 9.3 & 5.6 & 12.4 \\
\hline $\mathbf{T}_{2}: 15 / 25$ & 49.5 & 4.9 & 10.2 & 4.5 & 14.7 & 4.4 & 9.4 \\
\hline$T_{3}: 25 / 15$ & 51.2 & - & - & - & - & 5.8 & 11.0 \\
\hline$T_{4}: 25 / 25$ & 58.9 & - & - & - & - & 3.4 & 9.4 \\
\hline
\end{tabular}

$\left(1 \mathrm{~g}\right.$ fresh weight $=55 \mathrm{~cm}^{2}$ flag leaf.)

mean. To compare the organs, attention should be paid to the fresh weight ratio of these organs per plant; here the ratio for flag leaf, peduncle and ear was $1: 4: 15$. So per plant the respiration of the ear is much higher than that of the leaf.

\section{Influence of light intensity}

Seed yield and growth rate of the grains gave a higher response to an increase of light intensity from 92 to $142 \mathrm{cal} \mathrm{cm}^{-2}$ day-1 $^{-1}$ than to an increase from 147 to $175 \mathrm{cal} \mathrm{cm}^{-2}$ day-1 (Fig. 4).

During the first two weeks after flowering the weight of the peduncle as well as the weight of the other internodes was significantly increased by a higher light intensity. This means that shortly after flowering there is some basipetal transport of assimilates in the plant. The amount of downward transport, however, will depend on the supply and on the storage of assimilates in the ear; the remainder of assimilates will be stored mainly in the stem.

The advantage of a higher light intensity for grain growth was partly reduced by the more rapid leaf senescence. With 92,147 and $175 \mathrm{cal} \mathrm{cm}^{-2}$ day-1 $^{-1}$ the leaf area per culm three weeks after flowering amounted to $45.7,41.5$ and $36.5 \mathrm{~cm}^{2} \mathrm{culm}^{-1}$, respectively. 


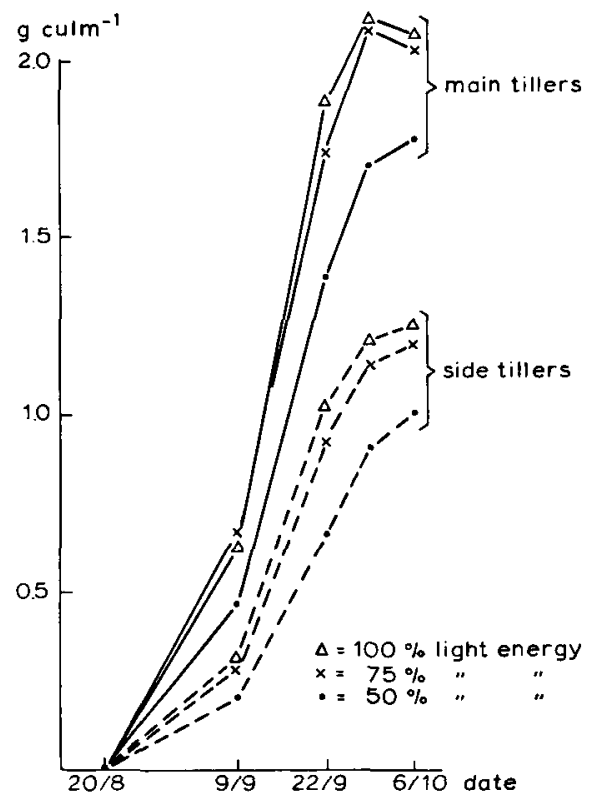

Fig. 4. The influenced of light intensity on grain growth of main and side tillers (data of Group B).

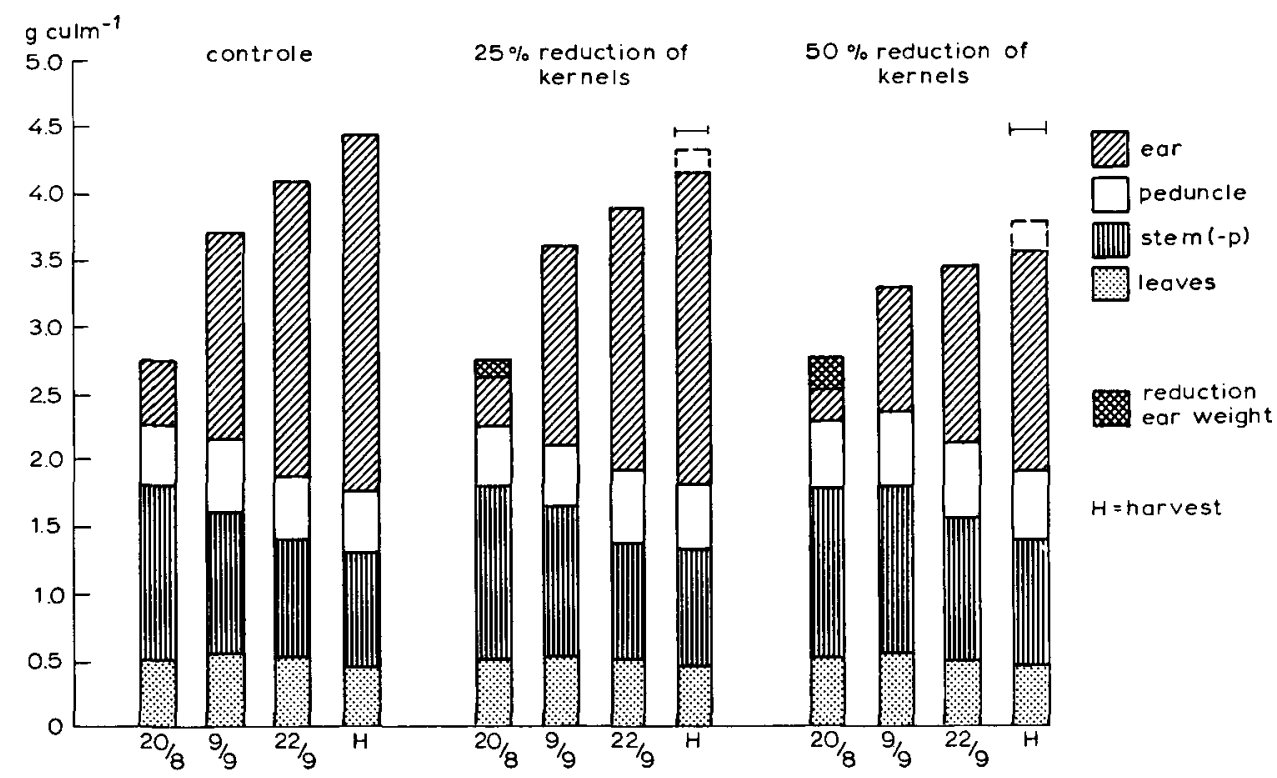

Fig. 5. The influence of ear size on dry matter distribution after flowering (data of Group A). 
Table 4. Grain weight of main culm and site culm with three different numbers of kernels per main ear (g ear-1).

\begin{tabular}{|c|c|c|c|c|c|c|}
\hline \multirow[t]{2}{*}{ Dates } & \multicolumn{3}{|c|}{ Main culm } & \multicolumn{3}{|l|}{ Side culm } \\
\hline & $\begin{array}{l}S_{0} \\
\text { (control) }\end{array}$ & $\begin{array}{l}\mathrm{S}_{1} \\
(-25 \%)\end{array}$ & $\begin{array}{l}\text { S2 } \\
(-50 \%)\end{array}$ & $\begin{array}{l}S_{0} \\
\text { (control) }\end{array}$ & $\begin{array}{l}\mathrm{S}_{1} \\
(-25 \%)\end{array}$ & $\begin{array}{l}\mathrm{S}_{2} \\
(-50 \%)\end{array}$ \\
\hline \multirow{3}{*}{$\begin{array}{l}3 \text { weeks after flowering } \\
5 \text { weeks after flowering } \\
7 \text { weeks after flowering }\end{array}$} & 1.13 & 0.92 & 0.64 & 0.82 & 0.93 & 0.97 \\
\hline & 1.72 & 1.56 & 1.09 & 1.29 & 1.35 & 1.46 \\
\hline & 1.97 & 1.68 & 1.18 & 1.37 & 1.51 & 1.59 \\
\hline
\end{tabular}

\section{Influence of the ear size}

The storage capacity in the ear was reduced by removing some of the top and central spikelets. This interference resulted in three storage capacities with 47.0, 36.6 and 24.3 kernels per ear, respectively.

Because of the reduced storage capacity there was initially an increase in the dry weight of the peduncle and the other internodes; this increase was, however, not sufficient to compensate for the decrease of the ear weight (Fig. 5).

The differences in dry weight of the internodes diminished during ripening, those of the ear remained up to the mature stage. Striking was the fact that the removal of spikelets on the main culm resulted in a significant increase of the seed yield of the side culms (Table 4). This indicates that when the storage capacity of the main ear
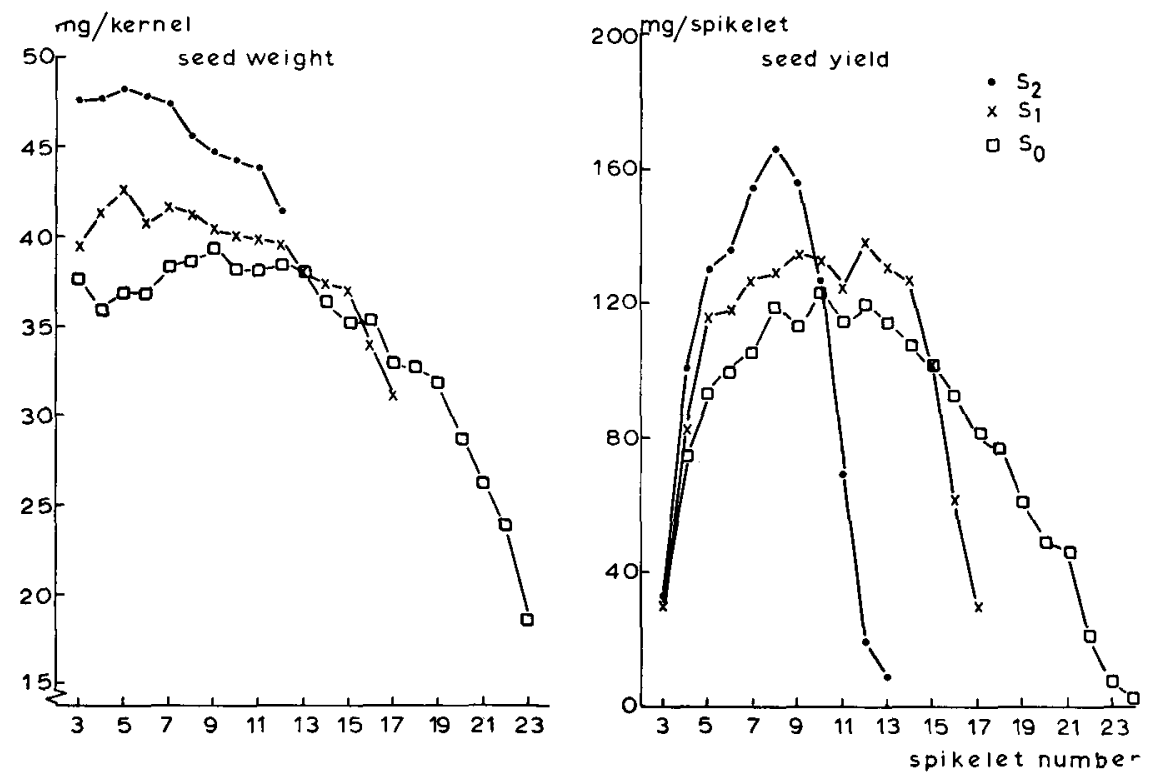

Fig. 6. The influence of the number of kernels per spikelets on individual grain weight and grain yield per spikelet (data of Group $A$ : averaged for $T_{3}$ and $T_{4}$ ). 
Table 5. The absolute growth rate (AGR) and the relative growth rate (RGR) of ear and kernels.

\begin{tabular}{|c|c|c|c|c|c|c|}
\hline & \multicolumn{3}{|l|}{ Ear } & \multicolumn{3}{|l|}{ Kernel } \\
\hline & $\begin{array}{l}S_{0} \\
\text { (control) }\end{array}$ & $\begin{array}{l}\mathrm{S}_{1} \\
(-25 \%)\end{array}$ & $\begin{array}{l}\mathrm{S}_{2} \\
(-50 \%)\end{array}$ & $\begin{array}{l}S_{0} \\
\text { (control) }\end{array}$ & $\begin{array}{l}S_{1} \\
(-25 \%)\end{array}$ & $\begin{array}{l}S_{2} \\
(-50 \%)\end{array}$ \\
\hline \multicolumn{7}{|c|}{$A G R(m g d a y-1)$} \\
\hline $20 / 8-9 / 9$ & 88.8 & 90.3 & 64.6 & 1.88 & 2.12 & 2.34 \\
\hline $9 / 9-22 / 9$ & 51.5 & 43.5 & 30.6 & 1.11 & 1.27 & 1.56 \\
\hline $22 / 9-6 / 10$ & 29.1 & 25.2 & 21.7 & 0.43 & 0.52 & 0.42 \\
\hline \multicolumn{7}{|c|}{$R G R\left(m g g^{-1} d a y^{-1}\right)$} \\
\hline $20 / 8-9 / 9$ & 98 & 124 & 148 & 259 & 304 & 370 \\
\hline $9 / 9-22 / 9$ & 25 & 25 & 27 & 5 & 6 & 4 \\
\hline $22 / 9-6 / 10$ & 13 & 12 & 14 & 38 & 38 & 41 \\
\hline
\end{tabular}

is very limited there is a downward flow of assimilates, which probably indirectly (e.g. by means of a better root activity) favours the grain growth in the side culms.

The most important compensation for the reduction in number of kernels per ear was a considerable increase of the individual kernel weight. So the initial $50 \%$ reduction in kernel number resulted in a $25 \%$ increase of the kernel weight. By removing the top spikelets, the kernel weights of the spikelets on the basal part of the ear were favoured by the additional supply of assimilates (Fig. 6).

To analyse the effect of different ear sizes on the physiological activity of the ear and the kernels as a storage organ the absolute and the relative growth rate have to be compared (Table 5).

The absolute growth rate of the total ear was decreased by reducing the ear size, whereas the growth rate of the individual kernel was increased up to the ripening stage. Difference in ear size affected the relative growth rate only a fortnight after flowering in such a way that the growth rate of both the total ear and the individual kernel were increased corresponding to the reduction in ear size. During the remainder of the kernel filling period there were hardly any differences in relative growth rate. Obviously in that phase there is a factor other than carbohydrate supply which is limiting the growth rate.

The content of water-soluble carbohydrates (wsc)

Before anthesis water-soluble carbohydrates accumulate in the stem. The contribution of these stem reserves to grain growth depends on the growing conditions. However, in the wheat plant the stem acts as a pool of available carbohydrates which increases with a surplus of photosynthates and decreases with consumption of carbohydrates, either by respiration or by retranslocation. The extend to which this pool was affected by temperature and light intensity is presented in Table 6 .

From flowering onwards the content of water-soluble carbohydrates of the stem was strongly affected by temperature as well as by light intensity. The lower wsc content at higher temperatures might be caused by a more rapid retranslocation to the kernels, by a higher respiration rate of the stem or a greater carbohydrate consumption by the roots. Especially at lower temperatures higher light intensities resulted in an increased wsc content; so under low temperature conditions there is a greater surplus of carbohydrates than at higher temperatures. 
Table 6. The content of water-soluble carbohydrates of the peduncle and the remaining internodes of the stem (Group B) at different temperatures ( $T_{1}$ etc.) and light intensities $\left(L_{1}\right.$ etc).

\begin{tabular}{|c|c|c|c|c|c|c|c|c|c|c|c|c|}
\hline & \multicolumn{3}{|l|}{$\mathbf{T}_{1}$} & \multicolumn{3}{|l|}{$\mathrm{T}_{2}$} & \multicolumn{3}{|l|}{$T_{3}$} & \multicolumn{3}{|l|}{$\mathrm{T}_{4}$} \\
\hline & $\overline{L_{1}}$ & $\mathrm{~L}_{2}$ & $\mathrm{~L}_{3}$ & $\mathrm{~L}_{1}$ & $\mathrm{~L}_{2}$ & $\mathrm{~L}_{3}$ & $\mathbf{L}_{1}$ & $\mathrm{~L}_{2}$ & $\mathbf{L}_{3}$ & $\mathrm{~L}_{1}$ & $\mathbf{L}_{2}$ & $\mathrm{~L}_{3}$ \\
\hline \multicolumn{13}{|c|}{ Peduncle } \\
\hline $9 / 9$ & 15.3 & 18.8 & 22.4 & 8.4 & 20.2 & 20.9 & 6.7 & 10.5 & 15.6 & 7.2 & 8.5 & 13.4 \\
\hline $22 / 9$ & 15.0 & 21.4 & 24.4 & 3.1 & 9.1 & 11.0 & 1.4 & 1.7 & 3.5 & 1.0 & 1.2 & 1.3 \\
\hline $29 / 9$ & - & - & - & - & - & - & 1.4 & 1.4 & $?$ & 0 & 0.9 & 0.9 \\
\hline $6 / 10$ & 11.3 & 12.6 & 10.4 & 0.8 & 0.8 & 1.9 & - & - & - & - & - & - \\
\hline \multicolumn{13}{|c|}{ Lower internodes } \\
\hline $9 / 9$ & 28.2 & 29.9 & 35.1 & 24.9 & 25.1 & 30.2 & 20.8 & 21.7 & 23.4 & 10.2 & 11.7 & 15.1 \\
\hline $22 / 9$ & 24.5 & 28.1 & 29.2 & 8.9 & 12.2 & 14.2 & 2.4 & 2.8 & 3.0 & 2.3 & 2.8 & 2.8 \\
\hline $29 / 9$ & - & - & - & - & - & - & 1.0 & 1.5 & 2.4 & 0.7 & 1.0 & 1.1 \\
\hline $6 / 10$ & 11.7 & 13.4 & 18.0 & 1.1 & 2.5 & 1.5 & - & - & - & - & - & - \\
\hline
\end{tabular}

The reduction of the ear had a smaller effect on the wsc content: a reduction of the kernels per ear with $50 \%$ caused an increase in wsc content of about $15 \%$.

\section{Discussion}

It was stressed earlier that grain growth was determined by the supply of carbohydrate and the sink capacity of the ear. In this experiment the surplus of carbohydrates was varied by light intensity and temperature. It was found that reducing the light intensity from 175 to $92 \mathrm{cal} \mathrm{cm}^{-2}$ day $(400-700 \mathrm{~nm})$ did not decrease the grain yield proportionally. Also Willey (1965) found relatively small reductions in yield with shading experiments in the field during the grain filling period. Of course the magnitude of the mutual shading of the plants will depend on the number of culms and on the leaf area per culm. Generally, light competition during the pre-flowering phase has turned out to be more critical for grain yield than competition at a later stage (Willey, 1965; Puckridge, 1968; Fischer, 1972).

Temperature has influenced the supply of assimilates in various ways. First the senescence of the leaves was accelerated by raised temperatures and secondly the respiration of leaves, stem and ear was increased. Despite this increase of respiration, the growth rate of the kernels did not decrease, but was even greater. This indicates that there was up to 3 weeks after flowering no absolute shortage of assimilates at higher temperatures; only the content of wsc in the stem decreased rapidly. It is unknown whether a lower carbohydrate level in the plant causes a much faster rate of senescence; there is some evidence that with higher temperatures the movement of nitrogen from the leaves into the grain is greater. This may be an important factor affecting the leaf area duration. Studying the duration of post-anthesis development under field conditions, Marcellos \& Single (1971) found that an increase of the mean daily temperature from 17.5 to $22.5^{\circ} \mathrm{C}$ during the post-flowering period reduced the duration of this phase by about $30 \%$. In this phytotron experiment the effect of temperature was greater, which might be explained by the additional influence of the environmental temperature on the roots of the plants grown in pots. Under field 
conditions soil temperature is affected less by the aerial temperature and by diurnal variations in temperature.

The storage capacity of the ear depends on the potential size of the grains and on the number of grains (Bingham, 1967). The latter of these two components was artificially varied in this experiment after flowering; normally in a field crop the number of grains is predominantly affected by the growing conditions before flowering (Fischer, 1972). The potential size of the grains seems to be partly genetically controlled, but also temperature and light intensity affect the number of endosperm cells (Wardlaw, 1970). From recent work (Jenner \& Rathjen, 1972) it may be concluded that also the rate at which carbohydrate can accumulate in the ear is determined by the flow rate of sucrose into the grain. Jenner (1970) showed that the concentration of sucrose in the endosperm was closely related to the rate at which starch was deposited. However, the level of sucrose in the endosperm was not linearly related to the amounts of sucrose in the other parts of the ear. It was concluded that the transport of sucrose into the grains is in some way very restricted on the final stages of its passage into the endosperm.

In this experiment the sink capacity of the ear was determined by temperature and ear size; during the early phase of kernel filling temperature predominated over the effect of ear size by affecting the growth rate of the kernels (Fig. 7). The effect of ear size on the growth rate of the kernels was greater with higher temperatures; at $25{ }^{\circ} \mathrm{C}$ there was a decrease in the weight of individual grains with an increasing number of kernels per ear, while at $15{ }^{\circ} \mathrm{C}$ there was hardly any differences. Thus under circumstances with a fast growth rate of the kernels the supply of carbohydrates will be limiting. That is why the positive effect of a higher light intensity also was greater with raised temperatures. This phenomenon was confirmed by the effects of temperature and light intensity on the changes in thousand-grain weight during the kernel filling period (Fig. 8) and on the content of water soluble carbohydrates in the stem. At low temperatures the effect of a relative shortage of carbohydrates on the thousand-grain weight came about at a later stage of kernel filling.

The quantity of wsc in the stem may be considered as a balance between the production (photosysthesis of green tissues) and the consumption (respiration, starch formation, etc.) of assimilates. The data of Table 6 show very clearly that at low
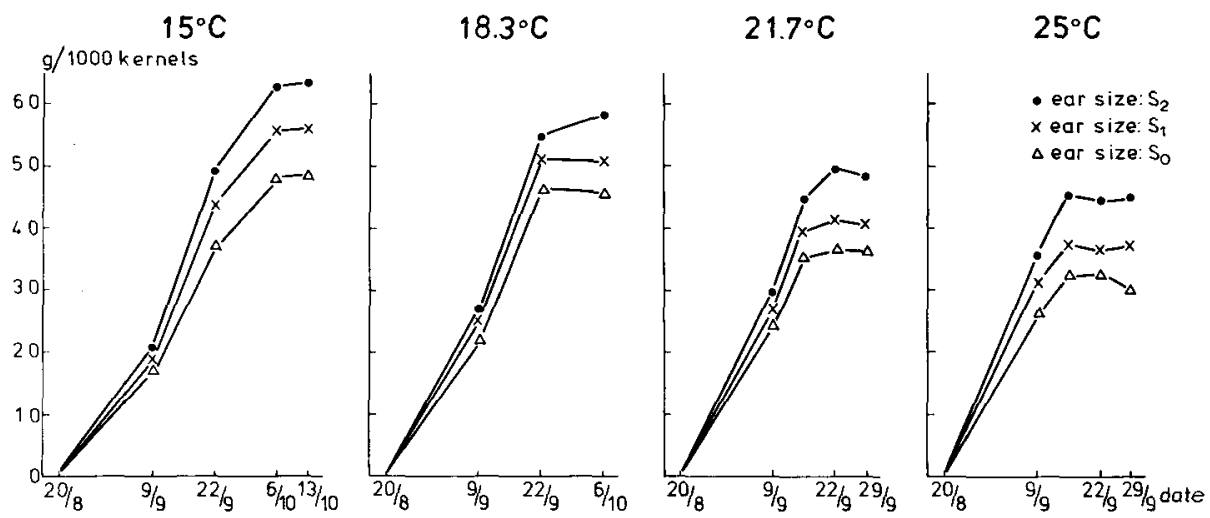

Fig. 7. The influence of temperature and ear size on thousand-grain weight (data of Group A) . 


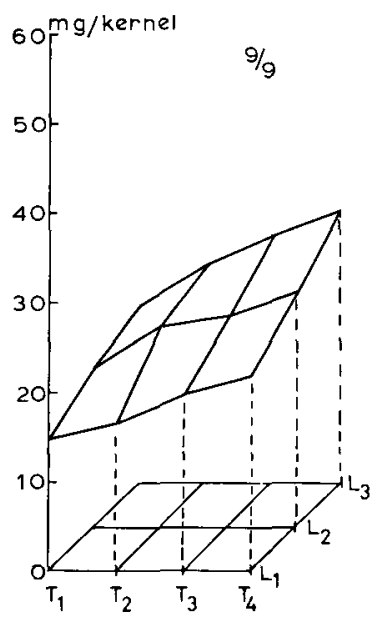

$$
\text { thousand-grain weight }
$$
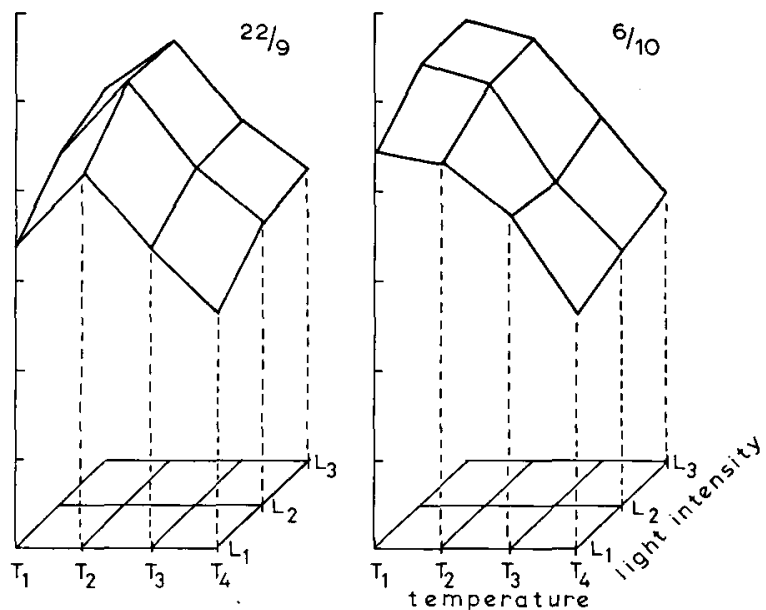

Fig. 8. The change in thousand-grain weight after flowering, as affected by temperature and light intensity (data of Group A: alone $S_{0}$ data).

temperatures there were initially higher contents of wsc in the stem, which decreased rather slowly during kernel filling. At high temperatures the wsc content in the stem decreased even in the early stage of kernel filling. This decrease of the wsc content will be caused mainly by increased respiration (Table 3) and by more retranslocation to the grains. The increased loss of stem sugars at higher temperatures is in agreement with the results of Asana \& Saini (1962).

The conclusion might be that the final grain yield depends on the balance between carbohydrate supply and ear capacity. The carbohydrate supply was determined by temperature and light intensity, because both climatic factors affected the net assimilation rate and the leaf area duration. Low temperatures together with high light intensities resulted in a surplus of available carbohydrates. Under such circumstances there must be a favourable effect of a greater ear capacity on grain yield; or one might also conclude, that with low temperatures during the kernel filling period a high light intensity is not necessary to achieve a normal grain weight. The storage capacity of the ear is more limited be removing the kernels from the central spikelets than from the top of the ear. The reduction in number of kernels per ear could only partly be compensated by an increase in thousand-grain weight. Temperature affected ear capacity by influencing the rate at which carbohydrate can accumulate in the ear. There is some evidence that various processes are involved, such as the translocation rate of assimilates, the passage of sucrose into the grain, the rate of converting sucrose into starch. To what extent these processes are important for grain growth and final grain size would be worthwile for further resarch.

\section{References}

Asana, R. D. \& A. D. Saini, 1962. Studies in physiological analysis of yield. V. Grain development in wheat in relation to temperature, soil moisture and changes with age in the sugar content of the stem and in photosynthetic surface. Indian J. Pl. Physiol. 5 (1/2): 128-171. 
Bingham, J., 1967. Investigations on the physiology of yield in winter wheat by comparisons of varieties and by artificial variation in grain number per ear. J. agric. Sci., Camb. 68: 411-422.

Bremner, P. M., 1972. Accumulation of dry matter and nitrogen by grains in different positions of the wheat ear as influenced by shading and defoliation. Aust. J. biol. Sci. 25: 657-668.

Carr, D. J. \& I. F. Wardlaw, 1965. The supply of photosynthetic assimilates to the grain from the flag leaf and ear of wheat. Aust. J. biol. Sci. 18: 711-719.

Evans, L. T. et al., 1970. The phloem of the wheat stem in relation to requirements for assimilate by the ear. Aust. J. biol. Sci. 23: 743-752.

Evans, L. T. \& H. M. Rawson, 1970. Photosynthesis and respiration by the flag leaf and components of the ear during grain development in wheat. Aust. J. biol. Sci. 23: 245-254.

Fischer, R. A., 1972. Grain production and source-sink relationships of a high-yielding semidwarf wheat. Paper presented to the A.S.A. meeting (Miammi, 1 November 1972).

Friend, D. J. C., 1965. Tillering and leaf production in wheat as affected by temperature and light intensity. Can. J. Bot. 43 (9): 1063-1076.

Friend, D. J. C., 1966. The effects of light and temperature on the growth of cereals: In: Milthorpe \& Evans (Ed.), The growth of cereals and grasses, 181-199.

Hanif, M. \& R. H. M. Langer, 1972. The vascular system of the spikelets in wheat (Triticum aestivum). Ann Bot., 36: 721-727.

Jenner, C. F., 1970. Relationship between levels of soluble carbohydrate and starch synthesis in detached ears of wheat. Aust. J. biol. Sci. 23: 991-1003.

Jenner, C. F. \& A. J. Rathjen, 1972. Factors limiting the supply of sucrose to the developing wheat grain. Ann. Bot. 36: 729-741.

Lupton, F. G. H., 1972. Further experiments on photosynthesis and translocation in wheat. Ann. appl. Biol. 71: 69-79.

Marcellos, H. \& H. V. Single, 1972. The influence of cultivar, temperature and photoperiod on postflowering development of wheat. Aust. J. agric. Res. 23: 533-540.

Michaël, G. et al., 1970. Einige Aspekte zur hormonalen Regulation der Korngrösse bei Getreide. Z. PflErnähr. Bodenk. 125: 24-35.

Puckridge, D. W., 1968. Competition for light and its effects on leaf and spikelet development of wheat plants. Aust. J. agric. Res. 19: 191-201.

Rawson, H. M. \& G. Hofstra, 1969. Translocation and remobilization of ${ }^{14} \mathrm{C}$ assimilated at different stages by each leaf of the wheat plant. Aust. J. biol. Sci. 22: 321-331.

Rawson, H. M. \& L. T. Evans, 1970. The pattern of grain growth within the ear of wheat. Aust. J. biol Sci. 23: 753-764.

Stoy, V., 1965. Photosynthesis, respiration and carbohydrate accumulation in spring wheat in relation to yield. Physiologia Pl., Suppl. IV: 1-125.

Walpole, P. R. \& D. G. A. Morgan, 1970. Quantitative study of grain filling in Triticum aestivum L., cultivar Maris Widgeon. Ann. Bot. 34: 309-319.

Wardlaw, I. F., 1970. The early stages of grain development in wheat: response to light and temperature in a single variety. Aust. J. biol. Sci. 23: 765-774.

Willey, R. W., 1965. Plant density and competition for radiant energy in wheat and barley crops. $\mathrm{Ph}$. D. Thesis, University of Leeds.

Yemm, E. W. \& A. J. Willis, 1954. The estimation of carbohydrates in plant extracts by anthrone. Biochem. J. 57: 508-514. 